\title{
CONTAGION EFFECT OF MACRO ECONOMIC VARIABLES ON IPO LISTING ACTIVITY: A TIME SERIES ANALYSIS IN INDIAN CONTEXT
}

\author{
POONAM RANI ${ }^{1}$ \& VEERPAUL KAURMANN ${ }^{2}$ \\ ${ }^{I}$ Research Scholar Punjab Technical University, Jalandher, Punjab, India \\ ${ }^{2}$ Giani Zail Singh Punjab Technical University, Bathinda, Punjab, India
}

\begin{abstract}
Boom and slump also occurs in Initial public offer segment of corporate securities market. Studies in context of developed capital market have exhibited that the macroeconomic variables, as well as market specific variables cause fluctuation in size and number of initial public offers (IPOs). This study, examines the relation between the financial market conditions (i.e. interest rate), total economy activity (GDP) and the IPO activity. Data from Jan 2004 to 2016 on quarterly basis was sampled for the purpose of the analysis. Co-integration and Granger Causality tests performed on variables namely number of IPO issue, issue size, interest rate and GDP. It was found that the interest rate has cointegration, but do not have causal relationship with number of IPO issues, as well as with size of IPO. GDP showed a significant causal relation with issue size, but insignificant one with the number of issue. Our findings contradict with the findings of Kaya (2013) and Lowery (2004). Finally, it is concluded that only GDP has a causal relationship with the size of IPO.

KEYWORDS: Initial Public Offers, Capital Market, Unit Root \& Co Integration Interest Rate
\end{abstract}

Received: Jun 30, 2017; Accepted: Jul 17, 2017; Published: Jul 31, 2017; Paper Id.: IJBMRAUG20174

\section{INTRODUCTION}

Indian capital market is a mature capital market. Its corporate securities segment works through two major stock exchanges i.e. BSE (Bombay Stock Exchange) and NSE (National Stock Exchange) established in 1855 and 1992, respectively. BSE is the oldest stock exchange in South Asia and NSE has got twentieth rank due to its market capitalization. Several regional stock exchanges are also functional in India. Corporate entities in India, float their equity instruments from a long time through these major stock exchanges, but some time they have approached regional stock exchanges simultaneously. IPO market in India enabling large scale corporate entities as well as SME's to raise long term finance. Several research activities have been conducted to understand the determinants of listing day return, performance of initial public offers, impact of IPO decision on capital structure and the waves of IPO. A small amount of research indicates the reason that works behind an IPO decision. Internal factor as well as macroeconomic environment works behind an informed decision making in context of IPO.

Economists have devoted a negligible amount of research, in order to understand the IPO process in Indian context. IPO market has a pro cyclical nature and it gets influenced by macroeconomic factor (lowery 2003). The present study examines the association among financial market condition, level of economic activities and level of IPO activities in primary market. The current study is an attempt to fill the gap in the literature by investigating 9year time series (2004 to 2013). 


\section{LITERATURE REVIEW}

IPO market enables an economy to mobilize resources from household and financial sector to production or service sector for productive investment activities. The factors which influence the economy as a whole, may influence the IPO market or vice a versa. IPO market is an important segment of the financial market. Alti (2005) developed a model of information spillovers in initial public offerings. He found that the IPO came in the market first; reveal the information on valuation factor from investor's perspective. The very same fact made the pricing of subsequent issue easier and allures more firms to step into the market. Market timing by the follower leads to create a positive wave called hot market condition. The decision of going public is sensitive to IPO market conditions. In 2006, Jain and Kini investigated 6,922 non financial firms, which had floated their equity instrument from 1980 to 1997. The study captured the herding behavior non financial firms in the sampled duration. The study points out that the firms which came during in clustering period do not have some qualitative difference from the firms, which came in non clustering period. Finally, the study sends a clear indication that there is no autoregressive relation of IPO activity in a particular segment. The result of the study was quite opposite to the study of the Alti (2006). Decision of listing not only depends upon the IPO market conditions, but also on the secondary market conditions. Bulm (2011) found, it is not the capital demand or investor sentiment, but the stock market conditions are responsible for fluctuations in IPO activities. High market to book ratio also evoke firms for listing, the ratio suggest a good time for listing (Boubaker et. al 2012, Sah et. al 2012). Listing leads to lose the internal control, management issuer always try to trade off the benefits of listing against the benefits of private control (pastor et. al. 2009). The review of the studies suggests that IPO market condition and firm's internal factor, as well as stock market condition both works beneath going public decision. Financial market condition (Kaya, 2013) influences the IPO market condition. Financial market condition is a leading indicator of IPO market activities. For fresh issue, the market condition plays an important role but for making a follow on issue, both the macroeconomic and firm related growth opportunity matters a lot (Quin, 2014), but activity related to fresh equity instruments falls in the scope of present study.

\section{OBJECTIVE OF THE STUDY}

From the literature review, we got a dimension that IPO activity implicitly have some relation with the total economy activity and financial market condition. The same fact motivated us to explore the same phenomenon in Indian capital market settings. The objectives of the present study are

To find out the causal relation among IPO activity, financial market condition and total economy activity

To find out the causal relation among real size of IPO, financial market condition and total economy activity

\section{METHODOLOGY \& DATA}

\section{Data \& Variable}

The present study was carried out using quarterly time series. Data from Jan 2004 to Dec 2016 sampled on GDP, Number of IPO issue, Size of IPO and interest rate.

Initially, GDP at factor cost on constant prices of 2004 was taken for the purpose of analysis after taking into account the seasonal factor; afterward the same time series data on GDP was converted into natural log form for final analysis.

The Total nominal size of IPOs in each quarter is divided by CPI of the respective quarter, in order to eliminate 
the impact of the inflation.

Call money rate was used as a proxy of financial market condition, because at this rate, bank offers money to meet the immediate requirement of funds. It has been assumed that the rate can take into account the immediate impact of financial market events.

Data on all is variables collected from the site of RBI (Reserve Bank of India) and SEBI (Security and Exchange Board of India).

\section{METHODOLOGY}

The study made use of standard Augmented Dickey Fuller (ADF) and Phillip Pherron (PP) test to check the order of integration of all variables. The first approach is parametric and the second one is a non-parametric approach. Under both approaches, the null hypothesis is

$\mathrm{H}_{0}$ : Series is non stationary or contains a unit root

ADF test rejects the null hypothesis at $1 \%$ level of significance. Hence, the results from ADF test clearly indicate that the time series data at level on each variable has unit root, but at first difference, each variable series achieved the stationary. Similar results were obtained through non parametric test, but the result of unit root test on real size of issue is different in PP test. PP test suggests that the variable real size of issue is stationary at level. In this context, we decided to go by the results of parametric test i.e. ADF.

Table 1: Augmented Dickey Fuller Test of Unit Root

\begin{tabular}{|l|c|c|c|c|c|}
\hline \multicolumn{1}{|c|}{ Variables } & \multicolumn{2}{|c|}{ ADF } & \multicolumn{2}{c|}{ ADF } & Outcome \\
\hline & $\begin{array}{c}\text { Test } \\
\text { Statistics } \\
\text { (Level) }\end{array}$ & P Value & $\begin{array}{c}\text { Test Statistic } \\
\text { (First Difference) }\end{array}$ & P Value & $\begin{array}{c}\text { I(0)= Level } \\
\text { I(1)=First Diff. Stationary }\end{array}$ \\
\hline No. of Issue & -3.332113 & 0.0520 & -6.8906 & $0.0000^{*}$ & I(1) \\
\hline Real Size & -2.83506 & 0.0629 & -12.19607 & $0.0001^{*}$ & $1(1)$ \\
\hline Gdp & -3.622785 & 0.1000 & -4.812896 & $0.0022^{*}$ & I (1) \\
\hline CM Rate & -1.751756 & 0.3981 & -5.816673 & $0.0000^{*}$ & I (1) \\
\hline
\end{tabular}

Note: * indicates the rejection of null hypothesis at $1 \%$ level of significance.

To determine the co integration among I (1) variables, Johenson test of co-integration has been applied on two different sets of variables. No of IPO issue in GDP and call money rate was kept in first panel and Real Size ( Real Size of IPO) in GDP and call money rate in second panel. The variables clubbed under first panel showed that at least one co integrating equation exists among them (See, Table 4).

Table 2: Philip Pherron Test of Unit Root

\begin{tabular}{|l|c|c|c|c|c|}
\hline \multicolumn{1}{|c|}{ Variables } & \multicolumn{2}{|c|}{ PP } & \multicolumn{2}{c|}{ PP } & Outcome \\
& $\begin{array}{c}\text { Test } \\
\text { Statistics } \\
\text { (Level) }\end{array}$ & P Value & $\begin{array}{c}\text { Test Statistic } \\
\text { (First Difference) }\end{array}$ & P Value & $\begin{array}{c}\text { I(0) = Level } \\
\text { I(1)=First Diff. Stationary }\end{array}$ \\
\hline No. of Issue & -3.443262 & 0.0530 & -8.874347 & $0.0001^{*}$ & I (1) \\
\hline Real_Size & -5.420502 & 0.0001 & --- & --- & I $(0)$ \\
\hline Gdp & -1.741637 & 0.7133 & -5.300987 & $0.0006^{*}$ & I (1) \\
\hline CM Rate & -1.838738 & 0.3569 & -5.842537 & $0.0000^{*}$ & I (1) \\
\hline
\end{tabular}

Note: * indicates the rejection of null hypothesis at $1 \%$ level of significance.

Same observation was noticed in from the variables namely Real size, ln GDP Call money rate. Finally, on the 
basis of statistical finding, it is held that at least two variables in each panel have long term relationship. In short run, these co integrated variable may move in either direction, but in long run their co-moment will bring these variables in an equilibrium stage.

Table 4: Jhohenson Test for Co-Integration (Series: No of ISSUE, LNGDP, CALL_MONEY_RATE)

\begin{tabular}{|l|c|c|c|c|}
\hline Hypothesized & Eigen value & Trace Statistic & $\mathbf{0 . 0 5}$ & Prob. \\
\hline No. of CE(S) & & & Critical Value & $(\boldsymbol{P}$ Value $)$ \\
\hline None & 0.409572 & 43.88163 & 47.85613 & $0.0509^{*}$ \\
\hline At most 1 & 0.296307 & 23.85912 & 29.79707 & 0.2065 \\
\hline At most 2 & 0.161492 & 10.50544 & 15.49471 & 0.2438 \\
\hline At most 3 & 0.095459 & 3.852453 & 3.841466 & 0.1125 \\
\hline
\end{tabular}

Note: Trace test indicates 1 co integration at the 0.05 level. * denotes rejection of the hypothesis at the

0.05 level.

Table 5: Jhohenson Test for Co- Integration

(Series: REALSIZE, LNGDP, CALL_MONEY_RATE)

\begin{tabular}{|l|c|c|c|c|}
\hline \multicolumn{1}{|c|}{ Hypothesized } & Eigen value & Trace Statistic & $\begin{array}{c}\mathbf{0 . 0 5} \\
\text { Critical Value }\end{array}$ & $\begin{array}{c}\text { Prob. } \\
\text { (P Value })\end{array}$ \\
\hline No. of CE(S) & & & 47.85613 & 0.0190 \\
\hline At most 1 & 0.539793 & 52.09475 & 29.79707 & 0.2661 \\
\hline At most 2 & 0.316104 & 22.60375 & 15.49471 & 0.4479 \\
\hline At most 3 & 0.151092 & 8.165693 & 3.841466 & 0.1635 \\
\hline
\end{tabular}

Note: Trace test indicates 1 co integration at the 0.05 level. * denotes rejection of the hypothesis at the 0.05 level

After visualizing the statistical evidence of co-integration; existence of a causal relationship among selected variables was tested through Granger test. The results of direct and reverse statistical test of causality on no. of issue and size of issue with $\ln G D P$ and call money rate are presented in Table 6 and 7. The table 6 presents the results of causality test for the variables lnGDP, No. of issue, Call money rate. The results in the table are presented in bi-variate from.

Table 6: Pair wise Granger Causality Tests [Testing for Causal Relationship among (Lngdp, No of Issue, Call Money Rate)]

\begin{tabular}{|l|c|c|c|}
\hline \multicolumn{1}{|c|}{ Null Hypothesis: } & Obs & F-Statistic & Prob. \\
\hline LNGDP does not Granger Cause NO_OF_ISSUE & 38 & 0.632 & 0.537 \\
\hline NO_OF_ISSUE does not Granger Cause LNGDP & & 0.295 & 0.745 \\
\hline CALL_MONEY_RATE does not Granger Cause NO_OF_ISSUE & 38 & 1.089 & 0.348 \\
\hline NO_OF_ISSUE does not Granger Cause CALL_MONEY_RATE & 1.691 & 0.199 \\
\hline
\end{tabular}

The first part of table 6 shows the causality between number of issue and lnGDP. The F- Statistic of Causality from $\operatorname{lnGDP}$ to number of issue is 0.632 and the p-Value is 0.537 , which clearly indicates that the null hypothesis of granger causality test cannot be rejected at $5 \%$ level of significance. In the second part of the same table, the F-statistic 1.089 of causality from call money rate toward number of issue (number of IPOs) has 0.348 -values so, null hypothesis of causality from call money rate to number of issue cannot be rejected. On the basis of statistical result, it is held that neither In GDP nor Call money rate have causal relation with No of issue. However, the Size of issue (See: Table 7) has a causal relation with ln GDP, where as it do not have any causal relation with call money rate.

Table 7: Pair wise Granger Causality Tests [Testing for Causal Relationship among (Lngdp, No of Issue, Call Money Rate)]

\begin{tabular}{|l|c|c|c|}
\hline \multicolumn{1}{|c|}{ Null Hypothesis: } & Obs & F-Statistic & Prob. \\
\hline LNGDP does not Granger Cause REALSIZE & 38 & 3.273 & $0.050^{*}$ \\
\hline REALSIZE does not Granger Cause LNGDP & & 0.267 & 0.767 \\
\hline CALL_MONEY_RATE does not Granger Cause REALSIZE & 38 & 1.206 & 0.312 \\
\hline
\end{tabular}




\begin{tabular}{|l|l|l|}
\hline REALSIZE does not Granger Cause CALL_MONEY_RATE & 0.805 & 0.455 \\
\hline
\end{tabular}

Note: * indicate rejection of null hypothesis at $5 \%$ level of significance.

\section{FINDINGS AND DISCUSSIONS}

From a battery of test, finally, it is established that during the period Jan 2004 to Dec. 2010, the number of IPO in Indian IPO market do not showed any fluctuation due to Interest rate and GDP growth. Corporate sector raised capital through equity instrument, irrespective of the financial market condition and total economic activity. The decision of equity floatation by the corporate sector was free from the prevailing economic conditions. But, the decision related to real size of issue exhibited influence of GDP growth because, statistically significant causality ( See: Table no. 6) from GDP growth to Size of issue is noticed, where as the interest rate has no causal relation with size of issue as well as with no. of issue. However, we cannot say how much effect of GDP growth is there, on real size of IPO.

\section{CONCLUSIONS}

Finally, it is concluded that the volume of activity in the IPO market has relation with growth in GDP. Hence, fluctuations in new issue market in term of volume of issue can be judged from the cyclical behavior of GDP.

\section{REFERENCES}

1. Aydogan Alt (2005), "IPO market timing” The Review of Financial Studies, 18(3), 1105.

2. Blum Rachel, 2011, "IPO Timing Determinants", Duke University, North Carolina, Durham.

3. Boubaker, A., \& Mezhoud, M. (2012), “Determinants of the IPO decision: French context”, Journal of Business Studies Quarterly, 4(1), 166-180.

4. Ibbotson R. G., and Jaffe J. J. (1975), “Hot issue markets.” Journal of Finance 30,1027-1042.

5. Jain, B.A. and Kini, O. (2006), "Industry clustering of initial public offerings", Managerial and Decision Economics, Vol. 27 No. 1, pp. 1-20.

6. Kaya D. H., “Empirical Study of Market Conditions and Initial Public Offerings : U.S Economy in perspective”, Journal of Financial Management and Analysis 26 (l), (2013): 65-74.

7. Lowery, M., and Schwert, G. W. "IPO market cycles: Bubbles or sequential learning?" Journal of Finance 57, (2002): 11711200.

8. Lucas, D. J., McDonald R. L. “Equity issues and stock price dynamics.” Journal of Finance 45, (1990): 1020-1043.

9. Mahmood, Faiq, Xinping Xia, Mumtaz Ali, Muhammad Usman, and Humera Shahid. "How Asian and Global Economic Crises Prevail in Chinese IPO and Stock Market Efficiency." International Business Research 4, no. 2 (04, 2011): 226-237.

10. Pagano, M., Panetta, F., \& Zingales, L. (1998). Why do companies go public? an empirical analysis. The Journal of Finance, 53(1), 27-64.

11. Pástor, Taylor, L. A., \& Veronesi, P. (2009). Entrepreneurial learning, the IPO decision, and the post-IPO drop in firm profitability.The Review of Financial Studies, 22(8), 3005-3046.

12. Qian, H. (2014). The timing of seasoned equity offerings: A duration analysis. Managerial Finance, 40(6), 565-586.

13. Ritter, J. R. “The “hot issue” market of 1980.” Journal of Business 57,(1980): 215-240.

14. Ritter, J. R. “The costs of going public.” Journal of Financial Economics, 18, (1987), 269-281. 
15. Sah, VivekSeagraves, Philip (2012) ," IPO market timing: evidence from the operating performance of REITs" Journal of Property Investment \& Finance, 3(1), 58-68.

16. Wang, Yongxiang. "Three Essays on Empirical Corporate Finance and Political Economy." 3420879, Columbia University, 2010. 